ГУЦАЛов Александр Анатольевич кандидат философских наук, ведущий научный сотрудник отдела изучения культурного наследия и экспертной деятельности Южного филиала Российского научно-исследовательского института культурного и природного наследия имени Д. С. Лихачева, Краснодар, Российская Федерация Alexander A. GUTSALOV

Cand. Sci. (History of Philosophy), Leading Researcher, Department for Heritage Studies and Expert Activities, Southern Branch, Russian Research Institute for Cultural and Natural Heritage, Krasnodar, Russian Federation gutsalov_alex@mail.ru

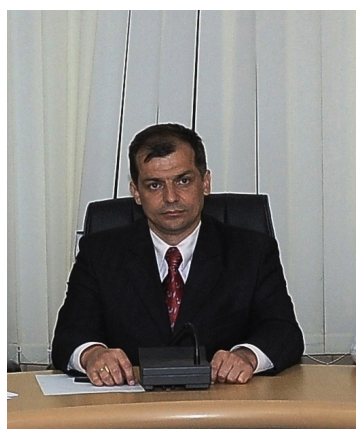

УДК [908+374.32]:[94(470)+ 303.094.5]

DOI: 10.36343/SB.2019.19.3.004

ГРНТИ 13.11.25

ВАК 24.00.01

\section{Молодежь и краеведение: исторический опыт и точки роста}

\section{Youth and Local History: Historical Experience and Growth Points}

В статье предпринята попытка осмыслить исторический опыт краеведческой деятельности и вовлечения в нее молодежи. Основной акцент сделан на исследование практики регионов Юга России. B XVIII-XIX вв. в нашей стране началось формирование понятийного аппарата краеведения, которое тогда обозначалось различными терминами: местнография, отчизноведение, отечествоведение, родиноведение. Особое значение имела деятельность краеведческих организаций в провинции. Южнороссийские краеведческие объединения представляли собой крупнейшие региональные центры распространения научных знаний, формирующие пространство коммуникации интеллигенции. Опыт развития краеведения в дореволюционной России оказался востребованным в дальнейшем. В 1920 -х гг. («золотое десятилетие краеведения») на Юге, как и в других регионах, возникли специализированные государственные институты; наряду с ними продолжалась деятельность общественных организаций. В постсоветский период активизация краеведческого движения происходила на фоне обострения межэтнических отношений и ослабления роли государства. Краеведческие исследования, проводимые вне контекста общероссийской истории, провоцировали мифологизацию образов прошлого, рост сепаратистских настроений в обществе, особенно в молодежной среде. Сформированный в последние годы положительный опыт сочетает разумное участие в краеведческой деятельности государства и его учреждений с развитием общественных инициатив.

Ключевые слова: краеведение, родиноведение, исторический опыт, локальные практики, молодежь, Юг России, исследовательские инициативы. 
Краеведение - это всестороннее познание определенной территории страны, трансляция и использование полученных знаний в социальной жизни. Всестороннее познание является результатом меж- и полидисциплинарного исследования. Объектами исследования в краеведении являются история, население, культура и быт, хозяйство, природа, географические, физические, экологические и иные особенности местности. Определяя понятие «краеведение», некоторые ученые подчеркивают в качестве его сущностной характеристики определяющую значимость участия именно местных жителей в познании родного края. Такое ограничение, думается, является неправомерным. К краеведению мы относим все исследования, а также использование полученных знаний, связанных с изучаемой территорией и народами, проживавшими и проживающими на ней.

Краеведение прошло эволюцию, обусловленную специфическими задачами своего времени. И определения дисциплины, призванной комплексно изучать различные регионы страны, менялись в зависимости от актуальных целей и задач.

Указы Петра I о поиске и собирании «диковинных» археологических, природных, исторических «редкостей», создание Академии наук преследовали цель всестороннего изучения богатств России с целью их эффективного использования.

М.В. Ломоносов заложил основы научного подхода к сбору сведений и составлению тщательных описаний объектов культуры, истории, природы. Именно ему принадлежит идея «запросов» - анкетирования с множеством вопросов по истории, экономике, географии и культуре. Они были разосланы вместе с особыми январским и декабрьским императорскими указами 1760 г. в разные регионы страны. Эти указы опирались на «доношение канцелярии Академии наук» и требовали от «Правительствующего Сената» принять меры к предоставлению «верных географических известий» «из всех губерний и провинций Российского государства» «для сочинительства нового исправнейшего Российского Атласа» [8, с. 17-18]. «Запросы» состояли из 30 вопросов в двух редакциях (Академии наук и Кадетского корпуса) [7, с. 22-32]. Фактически они стали первой программой изучения России.

В этой связи Академией наук были организованы экспедиции по изучению природы, топографии местностей, описанию памятников истории и культуры. Результаты этой работы были использованы в издании 17711774 гг. «Топографических известий...», вышедших под редакцией инспектора гимназии Академии наук Л. И. Бакмейстера [1]. В 1778 г. последовало издание Императорской Академии наук «Начертание общего топографического и физического описания Российской Империи...» [10]. Позже стали выходить схожие труды, посвященные отдельным территориям $[19 ; 12]$, а также описания путешествий (например, по Кавказу, Закавказью - И. А. Гильденштедта - 1787, 1791; Ю. Клапрота - 1812, 1814).

Таким образом, мы видим, что в условиях недостатка сведений о достоянии страны именно государство предпринимало усилия для решения этой проблемы, создавало научные кадры и организовывало экспедиции.

Новое знание рассматривалось компетентными современниками как педагогический и образовательный ресурс. Уже в 1780-х гг. было выпущено учебное пособие для народных училищ «Начертание естественной истории...» в двух частях $(1786,1789)$. Его автор Василий Федорович Зуев (1752-1794) призывал учителей обратиться к изучению и использованию находящихся в непосредственно окружающей природе растений и животных, рекомендовал проводить экскурсии с учащимися в горы, поля, леса. По мнению Василия Федоровича, это было необходимо для того, чтобы, во-первых, лучше узнать, что же мы имеем в нашей отчизне, а во-вторых, найти возможность «заменения» веществ «чужестранных» на отечественные: «А чтобы польза сего учения еще явственнее была в своей подробности, то каждое в наместничестве народное училище наипервое да примется за познание собственных своих произведений, которые, следовательно, наипервые и должны быть собраны, и, познавая соседственные, узнает, как у себя и чужие заводить, и свои размножать, удобрять и распространять должно» [4, с. 4]. 
И Ломоносов, и Зуев обращали внимание на важность привлечения к исследованиям местного населения, в частности, молодежи. Их идеи, опережающие свое время, воплотились значительно позже.

Одна из первых попыток понятийно оформить развивающуюся дисциплину была предпринята в публикации Евгения Болховитинова «Историческое, географическое и экономическое описание Воронежской губернии» (1800), где для обозначения самостоятельной отрасли истории предлагается термин «местнография».

Министерство внутренних дел в начале XIX века актуализировало необходимость «немедленного сбора по повелению императора следующих сведений по всем губерниям: в каких городах есть остатки древних замков и крепостей или других зданий, древности и в каком они положении ныне находятся» $[17$, с. 30$]$. В 1804 г. было создано «Общество истории и древностей Российских». За ним последовали и другие. Подробная их характеристика дана в монографии Дж. Брэдли [2].

Большое значение в области изучения и охраны культурного наследия имела деятельность возникших соответственно в 1834 и в 1884 гг. губернских / областных статистических комитетов и губернских ученых архивных комиссий. Кроме подготовки различной статистической информации, организации переписей и пр. статистические комитеты занимались экспедиционным изучением регионов, изданием сборников. 26 декабря 1837 г. было создано Министерство государственных имуществ. Тогда же чиновники и специалисты столкнулись с другой серьезной проблемой - научности и достоверности предоставляемых данных с мест. Объективно возникло несоответствие между все увеличивающимся потоком информации, потребностями ее систематизации и весьма ограниченным кругом лиц, имеющих право заниматься наукой: «... собственно наукой в этих обществах (Вольное экономическое общество, Московское общество сельского хозяйства, Русское географическое общество) занимался очень узкий круг лиц. Ни в Санкт-Петербурге, ни в Москве не было организации, куда запросто могли бы войти любители, чтобы напрямую заняться научными опытами» [2, с. 236].

Стремительный рост общественной инициативы, наблюдавшийся с середины XIX в., был связан с либерализацией сфер науки и образования. Снятие ряда ограничений при поступлении в университеты открыло доступ к высшему образованию более широких слоев населения. Стали массово создаваться научные общества (подробнее об этом [2, c. 237-252]). Очевидно, в те годы был найден удачный баланс между государством и обществом, способствовавший формированию гражданского общества, ставший благотворной основой для расширения научного изучения страны.

В 1860-х гг. понятийное оформление краеведения было продолжено. Николай Христианович Вессель (1837-1906) опубликовал в 1862 г. в нескольких номерах журнала «Учитель» ставшую знаковой статью «Местный элемент в обучении», в которой в обоснование использования местного материала в обучении школьников даже предлагал ввести особый предмет - «отчизноведение». Именно этот предмет, согласно его мнению, должен был стать базовым для всего образования.

Константин Дмитриевич Ушинский (1823-1870) в серии статей под общим названием «Педагогическая поездка по Швейцарии» в «Журнале Министерства народного просвещения» (1862-1863) описал систему элементарного, секундарного и высшего образования в Швейцарии того времени. В «Письме четвертом» (1863) он обратил особое внимание на предмет Heimats-Kunde (букв. родиноведение) в элементарной школе Фрелиха, который он, однако, перевёл как отечествоведение [22, с. 161, 164, 168-174]. Этот же предмет в секундарной школе был разделен на два: Vaterlands- и Welt-Kunde (букв. отечествоведение и мироведение) [22, с. 174]. Он писал: «Я давно мечтал о таком предмете, и потому очень обрадовался, встретив его здесь» [22, c. 175]. В статье он предложил разработать подобный предмет («отечествоведение») для начальной и средней школы в России, введя в него дополнительно кроме географии, истории и естествознания ещё и изучение родного языка, речи. Тогда же прозвучала идея, что 
изучение учащимися своего края является важным средством патриотического воспитания молодежи. Как справедливо заметил Г.Н.Ишук, «Ушинского можно назвать теоретиком национальной школы, которую он считал частью духовной культуры народа» [5, c. 52].

Под влиянием этих обсуждаемых в обществе идей последователь учения Ушинского Дмитрий Дмитриевич Семенов (1835-1903) издал в 1860 г. первый в России выпуск «Уроков географии», а Порфирий Николаевич Белоха (ок. 1810-1890) - полноценный «Учебник всеобщей географии» (1862). Третье его издание (1867) было дополнено «Программой для изучения места жительства или родины». В 1864 г. Семенов также издал «Педагогические заметки для учителей», являвшиеся, по сути, методикой преподавания географии, в которой прямо утверждался краеведческий принцип: «Единственным руководством для учеников должна быть книга для чтения с местным характером, где бы были подобраны статьи, касающиеся известной местности, на которой живут дети» [15, с. 252].

Характерно, что Семенов использовал в этой работе оба понятия - и «отчизноведение», и «отечествоведение». К первому он относил всё то, что ныне вкладывается в понятие «краеведение» (знание о малой родине), а ко второму - то, что мы пониманием под историей, культурой, природным и иным достоянием всей страны (большой родины). Он связывал эти предметы. Предшествующим в изучении отечествоведения выступало именно отчизноведение. Более того, отчизноведение понималось в качестве «начала естественных наук и истории» [15, с. 252].

Семенов, будучи в 1873-1883 гг. директором Кубанской и Закавказской учительских семинарий, вел большую педагогическую и научно-просветительскую работу на Юге России. В 1864-1887 гг. вышел фундаментальный шеститомный труд (сост. Д.Д. Семенов) «Отечествоведение», охватывающий описания Северного края и Финляндии (1864, том 1), Южного края - Малороссии, Новороссии, Крыма и земель Черноморского и Донского войск (1866, том 2), Кавказа и Урала (1871, том $3)$, Востока и Запада (1879, том 4), Великорус- ского края (1879, том 5), Туркестанского края (1887, том 6). Книги эти не раз переиздавались. Таким образом, в то время краеведение было осознано как базис образования и постижения наук. Отношение между отчизноведением как учением о малой родине и отечествоведением как учением о великой родине было очень удачно сохранено и подчеркнуто в понятии «родиноведение», которое с конца XIX в. стало активно использоваться в научной и популярной литературе.

В. Ф. Зуев, как мы отметили выше, еще в 80-х гг. XVIII в. предлагал ввести экскурсии, составление гербариев, различных коллекций из собранных предметов в процесс обучения. Практически эта работа начала активно внедряться в процесс образования лишь спустя столетие. Во второй половине XIX века Александр Яковлевич Герд (1841-1888) ввел в школьную программу демонстрационные опыты, экскурсионную работу. А один из основателей «Русского общества любителей мироведения», популяризатор родной русской природы профессор Дмитрий Никифорович Кайгородов (1846-1924) подготовил учебный курс «Краткий обзор растительного царства по климатическим поясам» (1885), комплексную программу по естествознанию (1901) для первых трех классов средней школы и хрестоматию для чтения в народной школе и семье «Из родной природы» $(1902,1912)$. Особенностью курса по естествознанию явилось деление учебных дисциплин не по предметам естественных наук, а по принципу «общежития природы» (лес, сад, река, поле, луг, парк и т. д). Изучение природы предлагалось проводить на прогулках и экскурсиях. Хотя эта программа, принятая в 1901 г., была раскритикована педагогической общественностью и затем пересмотрена и переработана Министерством просвещения, она содействовала развитию методики преподавания с опорой на местный материал.

Со временем путешествия, ведение путевых заметок, собирание сведений и коллекций становились всё более популярными. И в эту работу все более активно вовлекались молодые люди. В 1896 г. были изданы «Программы и наставления для наблюдений и собирания коллекций по естественной истории», выдер- 
жавшие позже еще три издания (в 1908, 1913, 1915 гг.) [13], а в 1905 г. - первое объемное, в 774 страницы, справочное пособие для путешественников [11].

Исследования южнороссийского региона входили в сферу деятельности академических и других научных учреждений, например, Общества любителей Кавказской археологии (основано в 1873 г., его покровителем стал великий князь Михаил Николаевич), отделения этнографии Императорского Русского Географического Общества. Значительную работу по сбору и публикации документов по истории, этнографии и культуре народов Юга России проводила Кавказская Археографическая комиссия.

На рубеже XIX-XX вв. на Юге появились общественные организации краеведческой направленности - Общество любителей изучения Кубанской области (1897), Кавказское горное общество (1902), Ставропольское общество для изучения Северо-Кавказского края (1910), Терское общество защиты и сохранения памятников старины (1915) и др. Общества разнились по уровню профессиональной подготовки их членов, но были объединены общим интересом. В отсутствие высших учебных заведений на Юге они являлись главными интеллектуальными центрами, ставившими перед собой задачу распространения научных знаний. Формировались общества вокруг незаурядных личностей, нередко сосланных из крупных городов по причине политической неблагонадежности [3, с. 14].

Информационное обеспечение краеведческой деятельности на Юге России осуществлялось посредством научных и справочных изданий. С 1845 г. (вплоть до 1916 г.) в Тифлисе выходил «Кавказский календарь», включавший с первого своего номера отдельные сведения и по Северному Кавказу. С 1883 г. стал выходить «Кубанский сборник», содержавший информацию по географическим, климатическим, природным, экономическим, археологическим, этнографическим, историческим вопросам. С 1899 г. Дагестанским областным статистическим комитетом публиковались сведения о народах Дагестана. Терский статкомитет во Владикавказе издавал Статистические таблицы населенных мест Терской об- ласти (1890-1891), Обзоры Терской области (с 1885 г.), Терский календарь (1891), Списки населенных мест Терской области (1878) и др. С 1868 г. печатались Сборники сведений о кавказских горцах.

Очевидна характерная взаимосвязь между увеличением объема знаний и сведений и развитием науки и, следом, образования. В этом процессе познание собственной местности, его истории и достояния могло бы стать фундаментальным в изучении наук. Однако, судя по всему, краеведение так и не стало отдельным предметом в учебных программах дореволюционной России, вопреки появлению многих учебных пособий краеведческой направленности, методических разработок, рекомендаций специалистов.

Общественная активность в отношении базирования образования именно на краеведении показывает, что последнее призвано к тому, чтобы обеспечить взаимосвязь между государственным управлением имуществом страны, наукой, широким доступом населения к истории и культуре, природе. Собственно, это и есть одна из форм реализации идеи гражданского общества. Понимание этой взаимосвязи вдохновляло многих ученых и педагогов начала XX в. разрабатывать практические методы преподавания различных дисциплин с опорой на сведения о местных природных, исторических и культурных объектах (методические разработки В. В. Половцева, Б. Е. Райкова, Л. Н. Никонова, К. П. Ягодовского, работы Э. Ю. Петри, С. П. Аржанова, А. А. Соколова).

В 1915 г. в Москве на I Всероссийском съезде учителей географии краеведение (родиноведение) было признано необходимым методическим средством преподавания. В 1916 г. в академическом издании очередного тома Словаря русского языка (1891-1930) появилась статья «краеведение», в которой оно определялось как «изучение данного края, страны». Причем ссылка на прежнее упоминание этого термина делалась на газетную статью 1914 г. под названием «Польское общество краеведения» [16, с. 2581]. Поэтому можно оспорить приписывание первого употребления термина «краеведение» историку В.Я. Уланову в его работе «Опыт методики истории в начальной школе» (1914). 
Методическая разработанность краеведческих исследований в дореволюционной России стала предпосылкой ее успешного развития в дальнейшем. Советская власть с первых лет своего существования осознала огромный потенциал краеведения и не жалела средств на его организацию. Разрушив прежние устои, она хотела как бы заново открыть наследие России, но уже под иным углом зрения.

В 1922 г. в Петрограде при Академии наук было создано Центральное бюро краеведения (ЦБК) и его региональные филиалы. Просуществовало оно до 1937 г. Председателем Бюро с 1922 по 1927 г. был знаменитый индолог академик С. Ф. Ольденбург. В 1924 г. ЦБК отделилось от Академии наук и стала самостоятельным органом. В 1930-1932 гг. ЦБК было переведено в Москву. Активность краеведческого движения в 1920-е гг. впечатляла. Количество краеведческих обществ и кружков в стране в 1927 г. увеличилось, по сравнению с дореволюционным периодом, с 61 до 1112 (то есть более чем в 18 раз), музеев - с 94 до 576 (более чем в 6 раз) [18, с. 301]. Даже если включить в число краеведческих организаций до революции ученые архивные комиссии, церковно-археологические комитеты, все региональные научные общества, то количество их не превысит 300. В 1923 г. в стране насчитывалось 516 краеведческих обществ, в 1929 году - уже более полутора тысяч [21].

Еще до учреждения Бюро, в 1921 г., был проведен Первый Всероссийский краеведческий съезд. Три последующих съезда (1924, $1927,1930)$ именовались Всесоюзными. В регионах проводились краевые, областные, уездные съезды (до 1927 г. свыше 100). В сентябре 1924 г. в Махачкале прошел учредительный съезд Северо-Кавказской горской краеведческой ассоциации, количество членов которой постоянно росло. В список, составленный Л. М. Ямпольским в 1927 г. вошло 96 краеведческих организаций на Юге России [23]. Некоторые из них были созданы еще в дореволюционное время и продолжали свою активную работу после революции (Общество любителей изучения Кубанской области).

В послереволюционное время были созданы Осетинское историко-филологическое общество (1919), Ассоциация кавказоведов
(1922), Кабардино-Балкарское общество изучения старины, этнографии и естественных богатств местного края (1922), Общество изучения Адыгейской автономной области (1924), Ингушское литературное общество (1924), Северо-Кавказское краевое бюро краеведения (1926) и др.

Создавались и научно-исследовательские учреждения. В 1920 г. во Владикавказе был открыт Северо-Кавказский институт краеведения, в 1924 г. в Дагестане - Институт национальной культуры (с 1938 г. Институт истории, языка и литератур). Были образованы Осетинский (1925), Кабардино-Балкарский (1926), Ингушский (1926), Адыгский (1929), Чеченский (1931), Черкесский (1932), Карачаевский (1932) научно-исследовательские институты краеведения. Координаторами этих институтов на Юге России выступали Северо-Кавказский институт краеведения во Владикавказе и сменивший его в этой роли Северо-Кавказский горский НИИ краеведения в Ростове-на-Дону (1927).

Выходили специальные издания по краеведению - «Краеведение» (1923-1929), «Известия Центрального бюро краеведения» (1925-1929), «Советское краеведение» (19301936). Более 150 краеведческих организаций в России имели свои периодические издания. На Юге России выходили «Известия» и «Бюллетени» Общества любителей изучения Кубанской области (всего 9 выпусков в 18991916 гг. и 3 - в 1922-1925 гг.), «Вопросы краеведения Адыгейско-Черкесской автономной области», «Бюллетень Северо-Кавказского Краевого Бюро Краеведения» и др.

В южнороссийских краеведческих изданиях значительное место отводилось молодежной проблематике. Например, А. Д. Князев в «Бюллетене Северо-Кавказского бюро краеведения» писал: «К краеведческой работе должны быть привлечены все ВУЗы, Техникумы и Рабфаки. <...> Чрезвычайно удачное соединение краеведческой работы с общественной деятельностью, с работой среди масс, приближает студенчество еще ближе к нуждам и запросам населения и, наоборот, приближает массы к ВУЗам, Рабфакам и техникумам...» [7, с. 23]. Автор полагал, что вовлечение учащейся молодежи в краеведческую 
работу приводит к повышению статуса образования, науки, создает платформу для коллективной работы над претворением в жизнь революционной идеи создания нового мира в Советской России. Если освободить это положение от идеологического ограничения, то оно и сейчас может быть использовано в решении задач построения гармоничного общества.

Наработанные в советские годы теоретические предложения и практическая работа по организации краеведческого движения среди молодежи могут и должны быть, по мнению А. Д. Князева, активно использованы. Это наполнение учебных планов краеведческим материалом, организация краеведческой работы во время каникул и на практике, кружковая и курсовые работы, активизация участия в экскурсионной, музейной, архивной работе, в различных институтах, секциях и подсекциях краеведческих организаций, в разработке планов исследовательской работы по краю и т. д. [7, с. 24].

Еще один автор «Бюллетеня Северо-Кавказского бюро краеведения» Д.И.Ястребов подчеркивал роль школьного краеведения, дискутируя с теми, кто настаивал на принципиальном разведении его с краеведением научным. По мнению Ястребова, вовлечение школьников в краеведческую работу является приобщением к науке, к постижению научных открытий и, по мере возможности, к исследовательской работе [24, с. 9-13].

Развитие краеведения в 1920-х гг. обусловило проникновение краеведческой тематики в школьные программы. Школьники не только потребляли готовые тексты, но и непосредственно вовлекались в исследовательский процесс. Активно проходили просветительские мероприятия и лекции, создавались школьные музеи, краеведческие кружки.

Однако последующий курс на тотальную идеологическую и культурную унификацию привел, в том числе, к репрессиям краеведов, закрытию краеведческих организаций, например, упомянутых выше Общества любителей изучения Кубанской области, Центрального Бюро краеведения со всеми его региональными филиалами, включая и Северо-Кавказское Бюро.
В конце 1940-х гг. краеведение стало постепенно «реабилитироваться». На государственном уровне поощрялся познавательный туризм. Выходили справочные туристические издания [20]. В работах ученых-географов А.С. Баркова (1873-1953), А.А. Половинкина (1887-1955), Н. Н. Баранского (1881-1963) и др. придавалось большое значение краеведению как основе и началу географического образования.

Новый виток развития краеведения относится к 1960-1980-м годам. В этот период появилось огромное количество высокопрофессиональных краеведческих работ, в том числе на Юге России. Можно назвать, например, труды осетинских краеведов Г. И. Кусова, Б. М. Бероева, Ю.В.Левковского, К.П.Попова, С. Ф. и В.С. Григоровичей и др. Краеведение было введено в школьные программы. К краеведческой деятельности широко привлекались школьники и молодежь. Формировались школьные музеи, пополняемые сведениями, собранными учениками. На Юге России создавались туристические маршруты местного и общесоюзного значения.

В постсоветский период активизация краеведческого движения происходила на фоне обострения на Юге России межэтнических отношений, «войн памяти». Краеведческие исследования играли важную роль в формировании национальной и локальной идентичности, особенно среди молодежи.

Задача этой статьи - не просто выявить точки роста (и спада) краеведческого движения в прошлом и настоящем, но и извлечь уроки, использовать наработанный опыт, чтобы в дальнейшем не повторять ошибок. Мы видим, что интерес (тем более стимулируемый государством) к познанию окружающего мира, истории людей, среди которых живешь, ведет к значительному повышению активности граждан, к их желанию получить образование, большей осознанности и, как следствие, к увеличению внутренней свободы. И здесь важно соблюсти баланс между государственным контролем и свободой граждан в познании окружающего мира. Государство должно выступать в роли координатора, доброго наставника, помощника в познавательных усилиях граждан, мягко корректирующего возможные 
недочеты и отклонения. При нарушении этого баланса (в сторону бесконтрольности или, наоборот, тотального контроля) развитие краеведения неизбежно оказывается под влиянием разнообразных искусственных идеологических построений.

В настоящее время государством созданы условия для свободного познания, для реализации своего краеведческого интереса всеми желающими. Никто не препятствует этой работе, не ограничивает образование, а краеведение уже не первый год входит в учебные планы средних и высших школ. Тем не менее краеведение, понятое ограниченно - как познание своей и только своей территории (региона, края, области, республики), — может заключать в себе и деструктивные смыслы для общего единства страны. В краеведении сейчас преобладает регионализм, стремление замкнуться на истории, культуре, природе лишь своего региона. Это зачастую приводит к мифотворчеству, использованию исторических сведений ради утверждения большей значимости своего народа с принижением роли других народов, а также с упорной зацикленностью на своей этнической, религиозной или территориальной культуре без всяких соотнесений с другими культурами.

Как преодолеть подобные тенденции, которые выявляются при актуальном анализе любого региона Юга России?

Ключ к решению данной проблемы мы находим в подходах ученых второй половины XIX в., когда понятия малой родины (отчизноведение) и великой родины (отечествоведение) органично объединялись как ступени единого образовательного и воспитательного процесса в понятии «родиноведение». Думается, современное краеведение должно быть переосмыслено с этой точки зрения. Историю и культуру какой-либо местности или народа в принципе невозможно понять и объективно воспринять вне общего историко-культурного контекста. Ресурс краеведения может и должен использоваться именно как точка входа в историю мировой цивилизации, в которой обретет свое достойное место и данный регион.

Кроме того, в новейший период развития краеведения следует отказаться от прак- тики оценочно-негативного отношения к своему прошлому, чтобы не повторять ошибок, сделанных в 1920-1930-х и в 1990-х гг., приведших к разрушению культурной сферы и уничтожению исторической и родовой памяти людей. Любой опыт прошлого, вне зависимости от того, позитивным он был или негативным, крайне важен для настоящего.

Новейшее время дало очередной толчок развитию краеведения. И мы пришли к пониманию того, что изучение достояния регионов и страны в целом не может ограничиваться лишь ответами на вопросы «Кто?», «Как?», «Когда?» и «Где?». Сегодня исследователи задаются вопросами «Зачем нам все это знать?» и «Как использовать это знание в повседневной жизни?» и пытаются ответить на них.

Современное краеведческое движение многогранно. Помимо всего прочего оно играет немаловажную роль в патриотическом воспитании молодежи. «Глубокие знания о „своей“ территории, ее специфике, людях, знаковых событиях в истории края и малой родины позволят эффективно решать задачу формирования патриотичного поколения школьников, которые любят свою Родину и разделяют современную систему ценностей», - справедливо полагает О. А. Кирьяш [6, с. 96-97].

Наше внимание привлекло историко-географическое общество «Друрдзуки» в Ингушетии [14]. Созданное группой единомышленников в 2015 г., оно за несколько лет успело провести внушительную работу (экспедиции в разные уголки Ингушетии, издание и презентация научно-популярной литературы, лекции, встречи, создание тематических видеороликов).

Основные участники проекта - молодые люди. На страничке этого общества в социальной сети «ВКонтакте» читаем: «Цель Общества состоит в консолидации сил и стремлений ингушской молодежи и широкой общественности в деле изучения и популяризации истории, культуры, проблем экологии и природных богатств Республики Ингушетия для сохранения национальной памяти и благотворных традиций, развития уникального этнокультурного своеобразия, рекреационных возможностей и формирования позитивного образа Республики Ингушетия». 
Собрать команду единомышленников удалось историку по образованию, бывшему научному сотруднику Ингушского НИИ гуманитарных исследований им. Ч. Ахриева (в 2009-2011 гг.), ныне заместителю председателя Совета местного самоуправления Назрановского муниципального района (с 2015 г.) Анзору Дударову.

Основные направления работы - научное,поисково-экспедиционное,экологическое, работа с молодежью. Общество реализует следующие проекты: «Орнамент - символ жизни», «Мудрость прошлого - Зиракий тІехьле», «Сады поколений», «Я познаю свой край», «Родники Ингушетии», «Спаси свою землю».

Проект «Орнамент - символ жизни» возник в связи с потребностью сохранить образцы уникальной ингушской орнаменталистики. Для этого были проведены десятки экспедиций в горы, исследовано более 60 архитектурных сооружений, собрано более 500 ковровых орнаментов, около 400 древних изображений на камнях архитектурных сооружений, более 100 барельефных изображений на стелах. Общество проводит курсы, обучающие искусству рукоделия, с целью сохранения культурных традиций и передачи их молодому поколению. Ведётся исследовательская работа в музеях всех регионов Северного Кавказа и Закавказья.

Проект «Мудрость прошлого» собрал людей, заинтересованных в сохранении воспоминаний пожилых людей о минувших днях и различных преданий, известных им с раннего возраста. Все эти материалы сразу становятся доступны на канале общества в «Youtube» и после необходимого оформления сдаются в Государственный архив Республики Ингушетия.

В рамках проекта «Сады поколений» в каждом населенном пункте республики открываются новые парковые зоны, осуществляется укрепление берегов рек посредством высадки вдоль них деревьев. В эту работу вовлекаются преимущественно молодые люди. Счет высаженным деревьям пошел уже на тысячи (к примеру, в с. п. Плиево, Троицкое, Кантышево, в г. Магас).

Проект «Родники Ингушетии» включает в свои планы облагораживание всех имеющихся родников региона.
Проект «Спаси свою землю» направлен на сбор использованных батареек в общеобразовательных организациях республики.

Кроме общественных инициатив в Малгобекском районе и в городе Нальчике созданы две бюджетные краеведческие учебные организации, одной из которых является Центр детско-юношеского туризма и краеведения под эгидой Федерального центра детско-юношеского туризма и краеведения при Министерстве культуры РФ. Подобные центры и станции функционируют и в Республике Северной Осетии - Алании (1), в Астраханской области (1), в Дагестане (9), в Чеченской Республике (14). Сочетание бюджетных, общественных и коммерческих форм организаций делает реализацию краеведческого потенциала более эффективной.

Группой краснодарских ученых было предпринято исследование вовлеченности молодежи в краеведческое движение с целью выявления основных проблем, точек роста, тем и направлений, которые на данном этапе являются наиболее значимыми. Были организованы встречи в разных регионах Юга России - Астраханской области, Дагестане, Северной Осетии - Алании, Ингушетии и Чечне - с молодыми людьми, студентами разных учебных заведений, с преподавателями и заинтересованными гражданами. Эти встречи помогли подтвердить актуальность выбранных для апробации направлений развития современного краеведения. Предложенные темы по литературному, театральному, историческому, малоизвестному пока научно-техническому наследию регионов получили живой отклик у молодежи и специалистов.

Апробация новых подходов к представлению природного и культурного наследия в общем информационном поле также оказалась в зоне повышенного внимания. Слушателям предложили поучаствовать в поиске образов, которые могут лечь в основу брендирования их родного края. И не было ни одного города, в котором бы молодежь не откликнулась на это предложение. Политика территориального брендирования является новой и удачной формой активизации молодежного участия в краеведческой работе, в которой кроме общественных, бюджетных организа- 
ций могут быть задействованы и коммерческие структуры.

Д.С. Лихачев отмечал: «Краеведение как явление культуры замечательно тем, что оно теснейшим образом позволяет связать культуру со строительством музеев, собраний, архивов, педагогической деятельностью, объединением молодежи в кружки и общества, развитием туризма, созданием хоров и кустарных артелей» [9, с. 173]. Исторический анализ развития краеведения подтверждает справедливость этого высказывания.

На основе представленного анализа можно сделать несколько выводов, касающихся развития и поддержки краеведческого движения, основной движущей силой которых должна выступать молодежь. Государство играет основную роль в организации краеведческого процесса. Именно оно создает образовательные, научно-исследовательские структуры, музеи, архивы, координирующие работу общественных краеведческих организаций. Результатом становится активизация населения в деле изучения локальной культуры и природы. Но, как показывает опыт, это имеет и определённую опасность - излишнего государственного контроля с одной стороны и бесконтрольности - с другой.

Выход мы видим в формировании системного подхода к планированию региональной культурной политики, который включал бы ряд факторов:

- сбалансированность государственной культурной политики, сочетающей контроль с максимальной открытостью и разумной свободой;

- повышение роли научного и экспертного сообществ в системе государственного контроля краеведческой деятельности;

- выстраивание многоярусной взаимосвязанной системы краеведческого движения в регионах: координирующие органы го- суправления, научные и образовательные организации, бюджетные специализированные учебные центры краеведения (причем открытые для обучения всех желающих, а не только детей определенного возраста, как сейчас), общественные организации, объединенные между собой в ассоциации, коммерческие туристические структуры и волонтеры;

- принципиальное расширение смысла краеведения, при котором оно перестанет ограничивать себя интересом изучения только «своей» территории, а осознает последнюю точкой входа в историю отечественной и мировой культур;

- углубление смысла краеведения с целью постижения его скрытых значений, важных для повседневной жизни граждан;

- объективное отношение к прошлому, преодоление крайностей в его оценках, принятие всего исторического опыта как неотъемлемой части исторической судьбы своего народа;

- возвращение из небытия забытых событий, имен и принятие всего комплекса наследия без купюр;

- активное развитие общегражданского самосознания, неотъемлемой частью которого является самосознание локальное (этническое, религиозное, территориальное);

- использование новых форм организации работы, новых средств популяризации культурных и природных объектов (технологии культурного брендирования территории).

Краеведение во всех своих организационных формах, с новыми творческими подходами призвано вовлекать молодежь в познание своей родины (малой и великой), развивать гражданское сознание, способствовать построению оптимальных, гармоничных отношений между народами, регионами, а также между государством и населением страны.

\section{Alexander A. GUTSALOV \\ Youth and Local History: Historical Experience and Growth Points}

Abstract. The article comprehends the historical experience of local history and young people's involvement in local history activities in order to identify the prospects of its development and growth 
points. The main emphasis is made on the study of the practice of Southern Russia's regions. Local history was conceptually designed in Russia in the 18th-19th centuries. It was designated by various terms: local studies, fatherland studies, national science, motherland studies. The leading actors of local history studies were academic institutions and public research organizations that were massively being established in the 19th century. Their initiatives objectively contributed to the development of traveling, to the engagement of representatives of various professional groups and youth in research, to the introduction of local history subjects into curricula. Public associations were the cells of the civil society formed in the Russian Empire and contributed to the formation of the all-Russia's and local identities. The activities of local history organizations in provinces were of particular importance. Southern Russia's associations such as the Society for the Study of the Kuban Region, the Caucasus Mountain Society, the Stavropol Society for the Study of the North-Caucasian Region, the Terek Society for the Protection and Preservation of Monuments were major regional distribution centers for the scientific knowledge that formed the communication space for the intelligentsia. Experience in the development of local history in pre-revolutionary Russia was in demand later. Specialized state institutions in the South and in other regions were established in the 1920s, the so-called "golden decade of local history". Along with them, the activities of public organizations continued. The multi-ethnic nature of the territory led to the creation of national research institutions, associations and societies. Specialized regional editions (Byulleten'Severo-Kavkazskogo byuro kraevedeniya [Bulletin of the North Caucasian Local History Bureau], etc.) paid special attention to involving youth and students in local history activities. The conflict between the diversity of local history topics and interpretations and the ideological strategy of the state to unify the life of society manifested itself in the 1920s. The dissolution of amateur local history associations in the early 1930s marked the total subordination of local history initiatives to the state. The activation of the local history movement in the post-Soviet period took place against the background of the aggravation of interethnic relations and the weakening of the role of the state. Local history studies, which were conducted outside the context of Russian history, provoked the mythologization of images of the past, the growth of separatist sentiments in society, especially among young people. The positive experience of local history, which was formed in recent years, combines the reasonable participation of the state and its institutions with the development of public initiatives. As an example, the article discusses the activity of the historical and geographical society Dzurdzuki (Republic of Ingushetia). The urgent tasks of identifying forgotten names and artifacts, issues related to the return to the modern cultural discourse of the memory of the events of national history make the development of literary, scientific, technical, archaeological, historical, ethno-cultural local history relevant. Local history as an important component of patriotic education of young people is directly connected with the solution of topical socioeconomic and cultural problems, with the development of domestic tourism, with the protection of historical and cultural monuments, as well as with cultural branding of territories.

Keywords: local history, homeland studies, historical experience, local practices, youth, South of Russia, research initiatives.

\section{Использованная литература:}

1. Бакмейстер Л. И. Топографические известия, служащие для полного географического описания Российской Империи. т. 1, ч. 1-4, СПб.: Имп. Акад. наук, 17711774.

2. Брэдли Дж. Общественные организации в царской России. Наука, патриотизм и гражданское общество. М.: Новый Хронограф, 2012.

3. Еремеева А. Н. Научная жизнь и научное сообщество Кубани в XX в.: очерки истории. Краснодар: Кубанькино, 2006.

\section{References:}

1. Bakmeyster, L.I. (1771-1774a) Topograficheskie izvestiya, sluzhashchie dlya polnogo geograficheskogo opisaniya Rossiyskoy Imperii [Topographic news for a complete geographical description of the Russian Empire]. Vol. 1. Parts 1-4. St. Petersburg: Imp. Akad. nauk.

2. Bradley, J. (2012) Obshchestvennye organizatsii $v$ tsarskoy Rossii. Nauka, patriotizm i grazhdanskoe obshchestvo [Voluntary Associations in Tsarist Russia: Science, Patriotism and Civil Society]. Translated from English. Moscow: Novyy Khronograf. 
4. Зуев В. Ф. Предисловие // Зуев В. Ф. Начертание естественной истории: изданное для народных училищ Российской империи по Высочайшему повелению царствующей императрицы Екатерины Второй: Ч. 1. СПб.: б. и., 1786.

5. Ищук Г. Н. Место краеведческой деятельности в школьном образовании // Вестник Академии детско-юношеского туризма и краеведения. 2012. № 4. С. 48-62

6. Кирьяш 0. А. Родиноведение - краеведение региональная история как структурные элементы патриотического воспитания в школе // Омский научный вестник. Серия Общество. История. Современность. № 3. 2017. С. 94-97.

7. Князев А. Д. Роль студенчества в краеведческом движении // Бюллетень Северо-Кавказского бюро краеведения. 1926. №1-2. С. 22-24.

8. Копия с Указа, какой послан из правительствующего Сената во все губернии, с приобщенными при нем Академией наук запросами // Бакмейстер Л. И. Топографические известия, служащие для полного географического описания Российской Империи. т. 1, ч. 1-4, СПб.: Имп. Акад. наук, 1771-1774. С. 17-32.

9. Лихачев Д. С. Краеведение как наука и как деятельность // Лихачев Д. С. Русская культура. М.: Искусство, 2000. С. 159-173.

10. Начертание общего топографического и физического описания Российской Империи, предпринятого Императорскою Санкт-Петербургскою Академией наук, СПб.: б.и., 1778.

11. Палибин И., Шмидт П. Ю., Шокальский Ю. М. Справочная книжка для путешественников. Санкт-Петербург: Изд. картографич. заведения А. Ильина, 1905.

12. Паллас П. Краткое физическое и топографическое описание Таврической области: Спб.: Имп. тип., 1795.

13. Программы и наставления для наблюдений и собирания коллекций по Естественной Истории. СПб.: Изд. Имп. С-петерб. об-ва естествоиспытателей. Тип. М. Стасюлевича, 1896.

14. Сайт Историко-географического общества «Дзурдзуки». URL: http://dzurdzuki.com/ (дата обращения: 17.08.19).

15. Семенов Д. Д. Педагогические заметки для учителей // Семенов Д. Д. Избранные педагогические сочинения. М.: Изд-во АПН РСФСР, 1953. С. 239-264.

16. Словарь русского языка, составленный Вторым отделением Императорской Академии наук. том 4. Вып. 9. Петроград.: Тип. Имп. Акад. наук, 1916

17. Смирнова О. В., Федосеенко Т. В. Научно-географические основы становления понятия «природное и культурное наследие» в географическом образовании // Современные проблемы науки и образования. 2015. № 4. C. 28-37.

18. Соболев В. С. Нести священное бремя прошедшего...: Российская Академия Наук. Национальное культурное и научное наследие. 1880-1930 гг. СПб.: Нестор-История, 2012

19. Соймонов П. А. Топографическое описание Калужского наместничества. СПб.: Имп. Акад. наук, 1785.

20. Справочник путешественника и краеведа / Под ред. С. В. Обручева, М.: Гос. изд-во географ. лит., 1949.
3. Eremeeva, A.N. (2006) Nauchnaya zhizn' i nauchnoe soobshchestvo Kubani v XX v.: ocherki istorii [Scientific life and the scientific community of the Kuban in the 20th century: essays on history]. Krasnodar: Kuban'kino.

4. Zuev, V.F. (1786) Predislovie [Foreword]. In: Nachertanie estestvennoy istorii: izdannoe dlya narodnykh uchilishch Rossiyskoy imperii po Vysochayshemu poveleniyu tsarstvuyushchey imperatritsy Ekateriny Vtoroy [The outline of natural history: published for public schools of the Russian Empire according to the Highest command of reigning Empress Catherine the Second]. Pt. 1. St. Petersburg: [s.n.].

5. Ishchuk, G.N. (2012) Mesto kraevedcheskoy deyatel'nosti v shkol'nom obrazovanii [The place of local history activities in school education]. Vestnik Akademii detsko-yunosheskogo turizma i kraevedeniya. 4. pp. 48-62.

6. Kir'yash, O.A. (2017) Studying Motherland: main approaches and problems of implementation. Omskiy nauchnyy vestnik. Seriya Obshchestvo. Istoriya. Sovremennost' - Omsk Scientific Bulletin. Series "Society. History. Modernity". 3. pp. 94-97. (In Russian).

7. Knyazev, A.D. (1926) Rol' studenchestva v kraevedcheskom dvizhenii [The role of students in the local history movement]. Byulleten' Severo-Kavkazskogo byuro kraevedeniya. 1-2. pp. 22-24.

8. Bakmeyster, L.I. (1771-1774b) Topograficheskie izvestiya, sluzhashchie dlya polnogo geograficheskogo opisaniya Rossiyskoy Imperii [Topographic news for a complete geographical description of the Russian Empire]. Vol. 1. Parts 1-4. St. Petersburg: Imp. Akad. nauk. pp. 17-32.

9. Likhachev, D.S. (2000) Russkaya kul'tura [Russian culture]. Moscow: Iskusstvo. pp. 159-173.

10. St. Petersburg Imperial Academy of Sciences. (1778) Nachertanie obshchego topograficheskogo i fizicheskogo opisaniya Rossiyskoy Imperii, predprinyatogo Imperatorskoyu Sankt-Peterburgskoyu Akademiey nauk [The outline of the general topographic and physical description of the Russian Empire undertaken by the Imperial St. Petersburg Academy of Sciences]. St. Petersburg: [s.n.].

11. Palibin, I., Shmidt, P. Yu. \& Shokal'skiy, Yu.M. (1905) Spravochnaya knizhka dlya puteshestvennikov [A reference book for travelers]. St. Petersburg: Izd. kartografich. zavedeniya A. Il'ina.

12. Pallas, P. (1795) Kratkoe fizicheskoe $i$ topograficheskoe opisanie Tavricheskoy oblasti [A brief physical and topographical description of Tauride Oblast]. St. Petersburg: Imp. tip.

13. Imperial St. Petersburg Society of Naturalists. (1896) Programmy i nastavleniya dlya nablyudeniy i sobiraniya kollektsiy po Estestvennoy Istorii [Programs and guidelines for observing and collecting natural history collections]. St. Petersburg: Izd. Imp. S-peterb. ob-va estestvoispytateley. Tip. M. Stasyulevicha.

14. Website of Dzurdzuki Historical and Geagraphical Society. [Online] Available from: http://dzurdzuki.com/. (Accessed: 17.08.2019). (In Russian).

15. Semenov, D.D. (1953) Izbrannye pedagogicheskie sochineniya [Selected pedagogical essays]. Moscow: Izd-vo APN RSFSR. pp. 239-264.

16. Second Division of the Imperial Academy of Sciences. (1916) Slovar' russkogo yazyka, sostavlennyy Vtorym otdeleniem Imperatorskoy Akademii nauk [Dictionary of the Russian language, compiled by the Second Division of 
21. Шмидт С. О. Краеведение [Электронный ресурс] // Энциклопедия Всемирная история. URL: https://w.histrf.ru/articles/article/show/kraieviedieniie (дата обращения 05.09.19).

22. Ушинский К. Д. Педагогическая поездка по Швейцарии («Журнал Министерства народного просвещения», 1862 г., № 12; 1863 г. №№ 1, 3, 4, 6) // Ушинский К. Д. Собр. соч.: в 11 т. Т. 3. М.-Л.: АПН РСФСР, 1948. С. 87254.

23. Ямпольский М. Л. Краеведческие учреждения на Северном Кавказе. Ростов-н/Д.: Сев.-Кавказск. краевое бюро краеведения, 1927.

24. Ястребов П. И. Школьное краеведение и общекраеведческая работа // Бюллетень Северо-Кавказского бюро краеведения. 1926. №3-4. С. 9-13. the Imperial Academy of Sciences]. Vol. 4. Is. 9. Petrograd.: Tip. Imp. Akad. Nauk.

17. Smirnova, O.V. \& Fedoseenko, T.V. (2015) Scientific and geographical bases of formation of the notion of natural and cultural heritage in geographic education. Sovremennye problemy nauki i obrazovaniya - Modern Problems of Science and Education. 4. pp. 28-37. (In Russian).

18. Sobolev, V.S. (2012) Nesti svyashchennoe bremya proshedshego...: Rossiyskaya Akademiya Nauk. Natsional'noe kul'turnoe i nauchnoe nasledie. 1880-1930 gg. [To bear the sacred burden of the past ....: Russian Academy of Sciences. National cultural and scientific heritage. 1880-1930]. St. Petersburg: Nestor-Istoriya.

19. Soymonov, P.A. (1785) Topograficheskoe opisanie Kaluzhskogo namestnichestva [Topographic description of Kaluga governorate]. St. Petersburg: Imp. Akad. nauk.

20. Obruchev, V. (1949) Spravochnik puteshestvennika i kraeveda [Handbook of a traveler and a local historian]. Moscow: Gos. izd-vo geograf. lit.

21. Shmidt, S.O. (n.d.) Kraevedenie [Local history]. [Online] Available from: https://w.histrf.ru/articles/article/ show/kraieviedieniie. (Accessed: 05.09.2019).

22. Ushinskiy, K.D. (1948) Sobranie sochineniy: v 11 t. [Collected works: in 11 vols]. Moscow-Leningrad: APN RSFSR. Vol. 3. pp. 87-254.

23. Yampol'skiy, M.L. (1927) Kraevedcheskie uchrezhdeniya na Severnom Kavkaze [Local history institutions in the North Caucasus]. Rostov-on-Don: Sev.Kavkazsk. kraevoe byuro kraevedeniya.

24. Yastrebov, P.I. (1926) Shkol'noe kraevedenie i obshchekraevedcheskaya rabota [Local history at school and general local history]. Byulleten' Severo-Kavkazskogo byuro kraevedeniya. 3-4. pp. 9-13.

\section{Полная библиографическая ссылка на статью:}

Гуцалов, А. А. Молодежь и краеведение: исторический опыт и точки роста [Электронный ресурс] / А. А. Гуцалов // Наследие веков. - 2019. - № 3. - С. 49-61. DOI: 10.36343/SB.2019.19.3.004

\section{Full bibliographic reference to the article:}

Gutsalov, A. A. (2019) Youth and Local History: Historical Experience and Growth Points. Nasledie vekov - Heritage of Centuries. 3. pp. 49-61. (In Russian). DOI: 10.36343/SB.2019.19.3.004 